\title{
The role of S100A1 in external auditory canal cholesteatoma
}

\author{
RAMIN NAIM and KARL HORMANN \\ Department of Otolaryngology, Head and Neck Surgery, University Hospital Mannheim, Germany
}

Received April 14, 2006; Accepted May 16, 2006

\begin{abstract}
S100 proteins were reported to be involved in different biological activities such as transduction of intracellular calcium signalling. It has been reported that each member of the $\mathrm{S} 100$ protein family exhibits a distinct tissue-specific pattern of expression. Furthermore, altered S100 protein expression and function correlate with many diseases. The expression of S100A1 was reported to be increased in different tissue with hyperplasia. The external auditory canal cholesteatoma (EACC) is a benign hyperplasia of the auditory meatal skin. However, without treatment, EACC destroys adjacent tissue. Seventeen EACC specimens were collected and investigated immunohistochemically against S100A1. Normal auditory meatal skin served as control. In the EACC, S100A1 showed a more homogeneous staining pattern, positively expressed throughout the epithelial layers. The keratin debris showed no detectable expression of S100A1. In the auditory meatal skin (control), S100A1 was only expressed in the basal layer of the epithelium. We showed that there are different staining patterns in normal auditory meatal skin, middle ear cholesteatoma and external auditory canal cholesteatomas. The immunoreactivity increased with the stage of the disease. Contrary to that reported previously in the middle ear cholesteatomas, the reactivity was strongest in the upper epithelial layers. In our collective, the epithelial matrix of the EACC showed strong reactivity throughout all the layers. Surprisingly, there is no study regarding the connection between growth factors and S100A1. In previous experiments we showed significant increase of growth factors in EACC. This correlates with our new data concerning S100A1. This is the first study to show the different reactivity pattern of S100A1 in the external auditory canal cholesteatoma.
\end{abstract}

\section{Introduction}

The S100 proteins were discovered in 1965 as a brain protein fraction. They were shown to consist of two different closely

Correspondence to: Dr Ramin Naim, Univ.-HNO-Klinik, TheodorKutzer-Ufer, D-68135 Mannheim, Germany

E-mail: ramin.naim@hno.ma.uni-heidelberg.de

Key words: external auditory canal cholesteatoma, S100A1, keratinocyte, proliferation related molecules, $\mathrm{S} 100 \alpha$ and $\mathrm{S} 100 ß$ (1). The S100 protein family constitutes with its 19 known members the largest subgroup of the EF-hand calcium-binding proteins. At least 13 S100 genes are clustered on human chromosome 1q21, with the resultant designations running from S100A1 to S100A13 (2). S100A1 binds calcium via EF-hand calcium-binding motifs and undergoes a conformational change that exposes a hydrophobic patch (3). This hydrophobic patch allows calcium receptor proteins, including S100A1, to interact with hydrophobic resins such as phenyl-sepharose, a property which is utilized in the purification of these proteins. If the hydrophobic patch is a major contributor to interaction with calcium-dependent target proteins, then its unavailability in the absence of calcium suggests that calcium-independent target proteins will utilize a different mechanism to interact with S100A1 (3). S100A1 is preferentially expressed in muscle, especially in myocardial tissue. It is present in the cytosol and found associated with the SR and contractile filaments. A number of observations indicate that S100A1 is a major regulator of cardiac contractility (4). However, S100A1 has been reported to be expressed in human tumors (5). Furthermore, Pelc et al showed that middle ear cholesteatomas also presented distinct reactivity to S100A1. They concluded that in contrast to S100B, the expression of S100A1, S100A2, S100A4 and S100A5 are often present in epidermoid cysts, branchial cysts, craniopharyngiomas and middle ear cholesteatomas. S100A3 and S100A6 (and, to a lesser extent, S100A5) were most dif-ferentially expressed across the different histopathological groups analysed (6). In the field of Otolaryngology, the external auditory canal cholesteatoma (EACC) is a very rare pathological entity (7). The EACC is usually found in the inferior or posterior part of the bony external ear canal, and it is characterized by permanent growth of the epithelial tissue (Fig. 1a and b) (8). Establishing the cholesteatoma, the epithelial layer is the socalled matrix, and the adjacent subepithelial tissue is called perimatrix. The matrix contains hyperplastic epithelial tissue which destructively, tends to grow into adjacent anatomical structures such as the bony canal and mastoid cells in contrast to keratosis obturans (9). Treatment of choice remains total surgical removal of the chronic inflammatory tissue (10). Some authors maintain post-operative, posttraumatic, post-inflammatory disorders as etiologic factors for EACC (11). Other authors claim circulatory disorders of local vessels supplying the epidermal layer of the tympanic membrane and the auditory canal as the etiologic factor for 

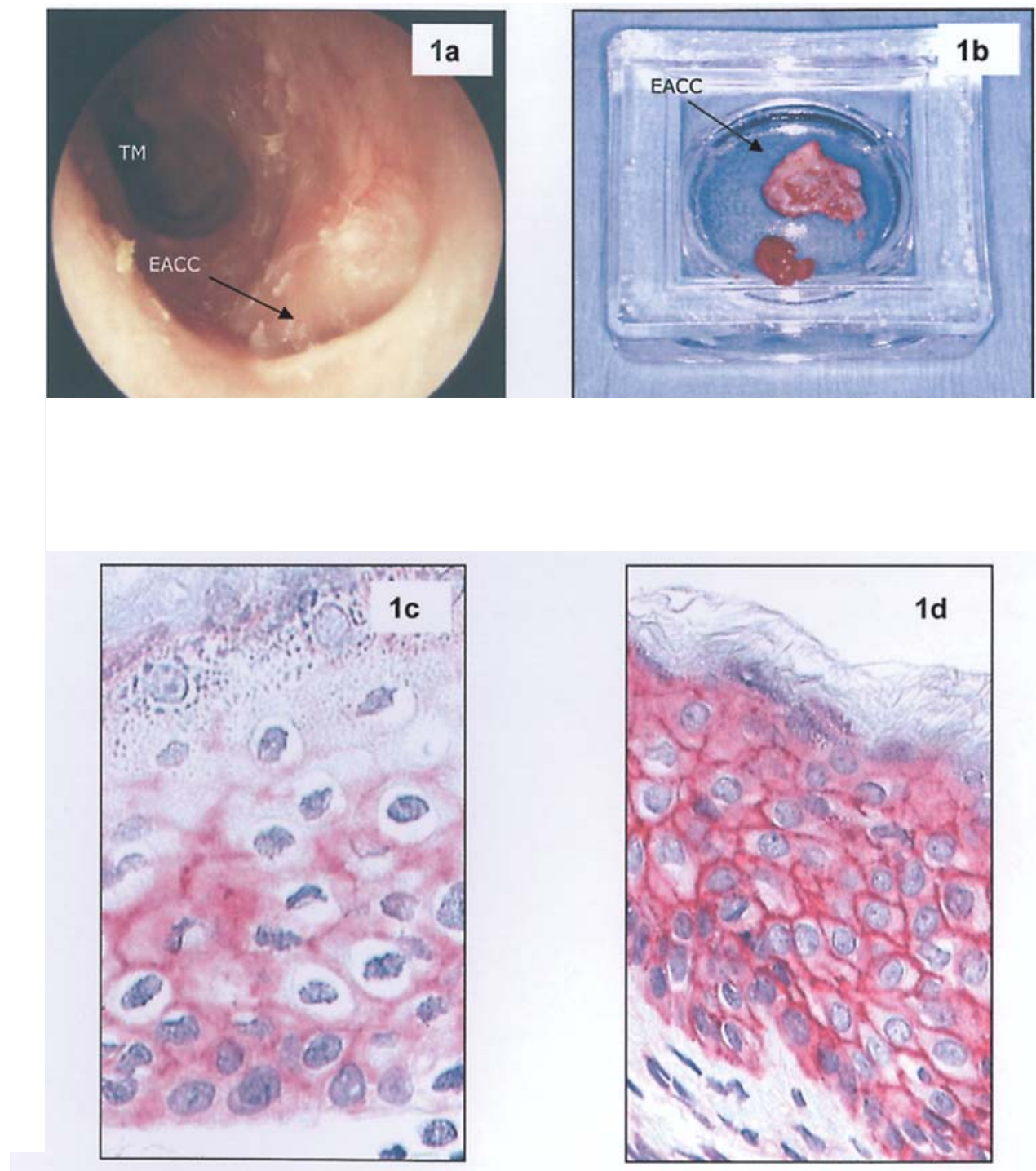

Figure 1. (a and b), Macroscopic aspect of the external auditory canal cholesteatoma (EACC). (c and d), Immunohistochemical investigation of normal auditory meatal skin (c) and external auditory canal cholesteatoma (EACC) (d).

disturbed epithelial migration in the area of the external auditory canal (10). We found that the angiogenic factors hepatocyte growth factor/scatter factor (HGF/SF), the tyrosine-kinase c-Met receptor, and vascular endothelial growth factor (VEGF) are all strongly expressed in the specimens of EACC (12). In comparison to keratinocyte culture, an in vitro study showed a higher baseline concentration of VEGF in the chole-steatoma cell culture (1.5- to 2-fold). Furthermore, stimulation of the cholesteatoma cells with $\mathrm{HGF} / \mathrm{SF}$ resulted in a strong proliferation rate and increased release of VEGF (13).

The aim of this study was to investigate to expression patterns of S100A1 protein in the EACC. Based on these results, we believe that S100A1 expression should be added into the panel of molecular markers for distinguishing EACC from different types of middle ear cholesteatomas.

\section{Materials and methods}

Collection of specimens. Between April 2000 and January 2005, 17 EACC specimens were collected from 17 patients undergoing surgery at the Department of Otorhinolaryngology of the University of Mannheim (normal auditory canal skin served as control tissue). The collected tissue was immediately fixed in formalin and embedded in paraffin. Two oto-laryngologists evaluated the specimens after hematoxylin and eosin staining. In each patient, the clinical data were reviewed in respect to age, sex, race, presenting symptom, side of the lesion and localization of the EACC (Tables I and II). The age of the patients ranged from 23 to 74 at the time of diagnosis (average age 50, median age 48). Except for one young patient (23 years), the patients in this study were elderly. Eleven patients were female and six were male. The patients were asked to describe their pain by characterizing the pain between 0 and 10 ( 0 , no pain; 10 , severe pain). In one case presenting stage IV EACC a high resolution temporal bone $\mathrm{CT}$ was performed. The patients were evaluated 4 and 8 weeks after surgery.

Immunohistochemical staining. Immunohistochemistry for S100A1 detection was performed by using a streptavidinbiotin complex procedure. Endogenous peroxidase was 
Table I. Histology and staging.

\begin{tabular}{|c|c|c|c|c|c|c|c|c|}
\hline \multirow[b]{2}{*}{ EACC no. } & \multicolumn{7}{|c|}{ Histology } & \multirow[b]{2}{*}{ Stage } \\
\hline & $\begin{array}{c}\text { Epithelial } \\
\text { hyperplasia }\end{array}$ & $\begin{array}{l}\text { Keratin } \\
\text { debris }\end{array}$ & Excavation & Periosteitis & $\begin{array}{l}\text { Bony } \\
\text { erosion }\end{array}$ & $\begin{array}{c}\text { Bony } \\
\text { sequester }\end{array}$ & $\begin{array}{l}\text { Infiltration of } \\
\text { adjacent tissue }\end{array}$ & \\
\hline 1 & $\mathrm{x}$ & $\mathrm{x}$ & $\mathrm{x}$ & $\mathrm{x}$ & & & & II \\
\hline 2 & $\mathrm{x}$ & $\mathrm{x}$ & $\mathrm{x}$ & $\mathrm{x}$ & $\mathrm{x}$ & $\mathrm{x}$ & & III \\
\hline 3 & $\mathrm{x}$ & $\mathrm{x}$ & $\mathrm{x}$ & $\mathrm{x}$ & & & & II \\
\hline 4 & $\mathrm{x}$ & $\mathrm{x}$ & $\mathrm{x}$ & $\mathrm{x}$ & & & & II \\
\hline 5 & $\mathrm{x}$ & $\mathrm{x}$ & & $\mathrm{x}$ & & & & II \\
\hline 6 & $\mathrm{x}$ & $\mathrm{x}$ & $\mathrm{x}$ & $\mathrm{x}$ & $\mathrm{x}$ & $\mathrm{x}$ & Mastoid & IV \\
\hline 7 & $\mathrm{x}$ & Obstruction & $\mathrm{x}$ & $\mathrm{x}$ & & & & II \\
\hline 8 & $\mathrm{x}$ & $\mathrm{x}$ & $\mathrm{x}$ & $\mathrm{x}$ & $\mathrm{x}$ & $\mathrm{x}$ & & III \\
\hline 9 & $\mathrm{x}$ & $\mathrm{x}$ & $\mathrm{x}$ & $\mathrm{x}$ & $\mathrm{x}$ & & & III \\
\hline 10 & $\mathrm{x}$ & $\mathrm{x}$ & $\mathrm{x}$ & $\mathrm{x}$ & & & & II \\
\hline 11 & $\mathrm{x}$ & $\mathrm{x}$ & $\mathrm{x}$ & $\mathrm{x}$ & $\mathrm{x}$ & $\mathrm{x}$ & & III \\
\hline 12 & $\mathrm{x}$ & $\mathrm{x}$ & & & & & & I \\
\hline 13 & $\mathrm{x}$ & $\mathrm{x}$ & & & & & & I \\
\hline 14 & $\mathrm{x}$ & $\mathrm{x}$ & $\mathrm{x}$ & $\mathrm{x}$ & & & & II \\
\hline 15 & $\mathrm{x}$ & $\mathrm{x}$ & $\mathrm{x}$ & $\mathrm{x}$ & & & & II \\
\hline 16 & $\mathrm{x}$ & $\mathrm{x}$ & & & & & & I \\
\hline 17 & $\mathrm{x}$ & $\mathrm{x}$ & $\mathrm{x}$ & $\mathrm{x}$ & $\mathrm{x}$ & $\mathrm{x}$ & & III \\
\hline
\end{tabular}

Table II. Patient characteristics.

\begin{tabular}{|c|c|c|c|c|c|c|c|c|c|c|c|c|c|c|c|c|c|}
\hline EACC no. & 1 & 2 & 3 & 4 & 5 & 6 & 7 & 8 & 9 & 10 & 11 & 12 & 13 & 14 & 15 & 16 & 17 \\
\hline Age & 37 & 34 & 45 & 56 & 23 & 68 & 74 & 53 & 66 & 48 & 71 & 53 & 45 & 48 & 37 & 33 & 55 \\
\hline Gender & $\mathrm{F}$ & $\mathrm{F}$ & M & M & $\mathrm{F}$ & $\mathrm{M}$ & $\mathrm{F}$ & $\mathrm{F}$ & $\mathrm{F}$ & $\mathrm{M}$ & $\mathrm{F}$ & $\mathrm{M}$ & $\mathrm{F}$ & $\mathrm{F}$ & $\mathrm{F}$ & $\mathrm{F}$ & M \\
\hline Pain ${ }^{\mathrm{a}}$ & 4 & 3 & 6 & 5 & 6 & 4 & 0 & 2 & 0 & 4 & 6 & 0 & 1 & 3 & 0 & 0 & 3 \\
\hline Otorrhea & + & + & + & - & - & + & + & + & + & - & + & - & - & - & + & - & - \\
\hline Loss of hearing & - & - & - & - & - & - & + & - & - & - & - & - & - & - & - & - & - \\
\hline Side $^{b}$ & $\mathrm{~L}$ & $\mathrm{~L}$ & $\mathrm{~L}$ & $\mathrm{R}$ & $\mathrm{L}$ & $\mathrm{R}$ & $\mathrm{L}$ & $\mathrm{R}$ & $\mathrm{R}$ & $\mathrm{R}$ & $\mathrm{L}$ & $\mathrm{L}$ & $\mathrm{R}$ & $\mathrm{R}$ & $\mathrm{L}$ & $\mathrm{L}$ & $\mathrm{R}$ \\
\hline \multicolumn{18}{|l|}{$\begin{array}{l}\text { Location in the } \\
\text { auditory canal }\end{array}$} \\
\hline \multicolumn{18}{|l|}{ Superior (between 10-1 o'clock) } \\
\hline Anterior (between 1-4 o'clock) & & & & & & & & & & $\mathrm{x}$ & & & & & & & \\
\hline \multicolumn{18}{|l|}{ Inferior (between 4-7 o'clock) } \\
\hline Anterior inferior & $\mathrm{x}$ & & & & & & & & & & & & & & & $\mathrm{x}$ & \\
\hline Middle & & $\mathrm{x}$ & $\mathrm{x}$ & & & & & & $\mathrm{x}$ & & & $\mathrm{x}$ & $\mathrm{x}$ & & & & \\
\hline Posterior inferior & & & & $\mathrm{x}$ & $\mathrm{x}$ & & $\mathrm{x}$ & $\mathrm{x}$ & & & $\mathrm{x}$ & & & $\mathrm{x}$ & $\mathrm{x}$ & & $\mathrm{x}$ \\
\hline Posterior (between 7-10 o'clock) & & & & & & $\mathrm{x}$ & & & & & & & & & & & \\
\hline
\end{tabular}

${ }^{\mathrm{a} N o}$ pain, 0 ; strong pain, $10 .{ }^{\mathrm{b}} \mathrm{R}$, right; $\mathrm{L}$, left.

blocked with $0.3 \%$ hydrogen peroxide for $30 \mathrm{~min}$. Sections were washed with phosphate-buffered saline (PBS) and incubated with normal sheep serum in PBS for $30 \mathrm{~min}$ at room temperature to block non-specific antibody reactions. The sections were then incubated overnight at $4^{\circ} \mathrm{C}$ with the primary anti-body [S100A1 (C20), sc \#7849, Santa Cruz, Heidelberg, Germany]. The slides were washed in several changes of PBS. The sections were then incubated with a peroxidase-conjugated secondary antibody (Dako, Hamburg, Germany). After being washed twice in PBS, sections were 
treated with a streptavidin-biotin-peroxidase complex and peroxidase reaction was performed using aminoethylencarbazol (AEC) (Dako) as chromogen. The different antibodies were diluted to the desired concentrations in PBS. Bright field microscopy was used to analyse the cells and was performed using a Zeiss Axiophot microscope. Epithelial tumor tissues and normal auditory meatal skin served as positive controls. The degree of immunohistochemical staining was evaluated semi-quantitatively by two examiners separately. To describe the slides the stainintensity was evaluated (strong, $>80 \%$ positive cells; moderate, $50-80 \%$ positive cells; week, $<50 \%$ positive cells; and no positive cells).

\section{Results}

In the auditory meatal skin (control), S100A1 was expressed in the basal layer of the epithelium (Fig. 1c). The expression was predominantly located in the cytoplasm of the cells. The expression of S100A1 decreased towards the surface of the normal epithelium (Fig. 1c). The keratin debris showed no detectable expression of S100A1. In the EACC, S100A1 showed a more homogeneous staining pattern, positively expressed throughout the epithelial layers (Fig. 1d). The perimatrix of all the specimens also showed faint to moderate positive staining. One specimen showed no staining of the apical part of the epithelium. This was diagnosed at an early stage of disease without excavation of the epithelium and adjacent periosteitis of the bony canal. The keratin debris of the EACC specimens showed no staining (Fig. 1d). The immunoreactive status of the basal membrane was strongly reactive in the EACC, however, in the normal tissue the reactivity was weak.

\section{Discussion}

In this study we showed that obviously there are different staining patterns in normal auditory meatal skin, middle ear cholesteatoma and external auditory canal cholesteatomas. The absent reactivity against S100A1 in the keratin layer is common among the different types of the entities. The apical keratin layer is comprised of dead cells with no intracellular signalling. There is increasing evidence that S100 proteins play an important part in calcium signalling pathways, and that each member of the $\mathrm{S} 100$ protein family exhibits a distinct tissue-specific pattern of expression (2). However, the epithelial part of the different specimens showed different expression of S100A1. The EACC matrix showed strong reactivity against S100A1 (Fig. 1d). The immunoreactivity increased with the stage of the disease (Table I). The normal auditory meatal skin showed strong reactivity in the basal layers. The apical epithelial part showed faint to no immunostaining against S100A1 (Fig. 1c).

Pelc et al compared different benign epithelial tissue of the head and neck and stated that from a clinical point of view, epidermoid and branchial cysts are benign and non-aggressive lesions, in contrast to craniopharyngiomas and cholesteatomas, which are more aggressive and have a strong potential to recur and invade the surrounding tissue. They reported that in all cases, the acquired middle ear cholesteatomas showed the strongest positive staining of the different epithelial layers. In the cholesteatomas, the reactivity was strongest in the upper epithelial layers. The basal membrane was less positive (6). In our collective, the epithelial matrix of the EACC showed strong reactivity throughout all the layers. The basal membrane was also moderate to strongly reactive. This emphasizes the hypothesis that the level of positive reactivity against S100A1 is somehow linked to the degree of aggressiveness of the investigated tissue. The S100 proteins have become of major interest because of their differential expression in neoplastic tissues, their involvement in metastatic processes, and the clustered organization of at least $10 \mathrm{~S} 100$ genes on human chromosome 1q21, a region frequently rearranged in several tumors. Ilg et al reported that S100 is expressed in human tumors (5). Several authors reported that renal cell carcinomas showed significant immunoreactivity against S100A1. However, there was no significant correlation between the mutant p53 and S100A1. S100A1 was suggested to serve as a marker in judging the degree of malignancy and invasion of renal cell carcinomas (14). Surprisingly, there is no study regarding the connection between growth factors (VEGF, FGF-2, HGF, c-Met etc.) and S100A1. In previous experiments we showed significant increase of growth factors in EACC (in vitro and in vivo). This correlates with our new data concerning S100A1. While these previous studies suggest that S100A1 antagonists would be valuable in adjunct therapy in the treatment of some diseases, there is no information available regarding the target proteins with which S100A1 interacts to regulate cell proliferation or toxicity, nor have the molecular mechanisms of S100A1target protein interactions been ascertained. Both of these pieces of information are essential for the rational design of S100A1 antagonists.

In future, it is necessary to study the role of S100 proteins in different epithelial malignancies and their role in angiogenesis, growth and invasiveness of these tissues. This is the first study to show the different reactivity pattern of S100A1 in the external auditory canal cholesteatoma.

\section{Reference}

1. Moore B: A soluble protein characteristic of the nervous system. Biochem Biophys Res Commun 19: 739-744, 1965.

2. Schäfer B and Heizmann C: The S100 family of EF-hand calcium-binding proteins: functions and pathology. Trends Biochem Sci 21: 134-140, 1996.

3. Zimmer DB, Cornwall EH, Landar A and Song W: The S100 protein family: history, function and expression. Brain Res Bull 37: 417-429, 1995.

4. Most P, Bernotat J, Ehlermann P, Pleger ST, Reppel M, Borries M, Niroomand F, Pieske B, Janssen PM, Eschenhagen T, Karczewski P, Smith GL, Koch WJ, Katus HA and Remppis A: S100A1: a regulator of myocardial contractility. Proc Natl Acad Sci USA 98: 13889-13894, 2001.

5. Ilg EC, Schafer BW and Heizmann CW: Expression pattern of S100 calcium-binding proteins in human tumors. Int J Cancer 68: 325-332, 1996.

6. Pelc P, Vanmuylder N, Lefranc F, Heizmann CW, Hassid S, Salmon I, Kiss R, Louryan S and Decaestecker C: Differential expression of S100 calcium-binding proteins in epidermoid cysts, branchial cysts, craniopharyngiomas and cholesteatomas. Histopathology 42: 387-394, 2003.

7. Naim R and Linthicum F Jr: Temporal bone histopathology case of the month: external auditory canal cholesteatoma. Otol Neurotol 25: 412-413, 2004.

8. Holt JJ: Ear canal cholesteatoma. Laryngoscope 102: 608-613, 1992. 
9. Naim R, Shen T, Linthicum F Jr and Hormann K: Classification of the external auditory chanal cholesteatoma (EACC). Laryngoscope 115: 455-460, 2005.

10. Anthony PF and Anthony WP: Surgical treatment of external auditory canal cholesteatoma. Laryngoscope 92: 70-75, 1982.

11. Piepergerdes MC, Kramer BM and Behnke EE: Keratosis obturans and external auditory canal cholesteatoma. Laryngoscope 90: $383-391,1980$

12. Naim R, Riedel F, Gotte K, Bran G, Sadick H, Gossler U and Hormann K: Co-expression of different angiogenic factors in external auditory canal cholesteatoma. Acta Otolaryngol 124: 563-568, 2004.
13. Naim R, Sadick H, Bayerl C, Riedel F, Schafer C, Bran G and Hormann K: Hepatocyte growth factor/scatter factor induces VEGF in human external auditory canal cholesteatoma cell culture. Int J Mol Med 15: 67-71, 2005.

14. Yang JF, Zhang XY and Qi F: Expression of S100 protein in renal cell carcinoma and its relation with p53. Zhong Nan Da Xue Xue Bao Yi Xue Ban 29: 301-304, 2004. 